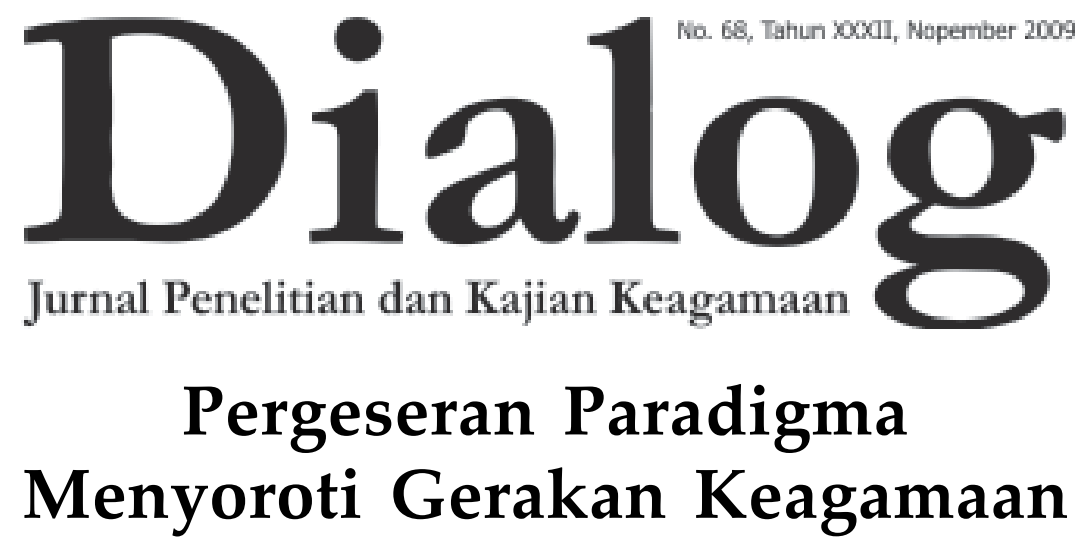




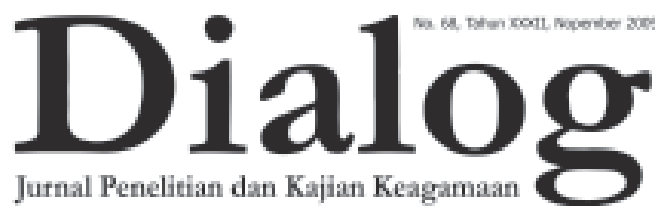

Pemi mpin Umum:

Prof. Dr. H. M. Atho Mudzhar, MA

Redaktur Ahli:

Prof. Dr. H. Nasaruddin Umar, MA

Prof. Dr. H. Komarudin Hidayat, MA

Pemimpin Redaksi / Penanggung J awab

Drs. H. Syamsuddin

Wakil Pemi mpin Redaksi

H. Fanani Suprianto, SH., MM

Sekretaris Redaksi

M. Rosyid Fauzi, S.Si.

Dewan Redaksı

Prof. Dr. H. Abdurrahman Mas'ud Drs. Amin Haedari

Prof. Dr. H. Maidir Harun

Drs. H. Mohammad Shohib, MA

Drs. H. Asmu'i, SH, MM

Chamdi Pamudji, SH., MM

Redaktur Eksekutif

M. Nasir, S.Th.I.

Redaktur Pelaksana

Moh. Rosyid Fauzi, S.Si

M. Nasir, S.Th.I

M. Adlin Sila, M.A

Abbas Jauhari, M.Ag

Administrasi

Drs. Dedy Curipno

Sutidjah

Desriyanti Nasution, S.IPI

Drs. H. Sahlani

Alamat Redaksi

Gedung Bayt Alquran Museum Istiqlal Komplek Taman Mini Indonesia Indah

Telp. (021) 87791444-87794982

Website:

www. balitbangdiklat.depag.go.id

Email:

info@depag.web.id

\section{Pergeseran Paradigma Menyoroti Gerakan Keagamaan}

Fenomena munculnya berbagai aliran keagamaan di Indonesia beberapa tahun terakhir menunjukan kecenderungan positif dalam kebebasan beragama. Namun sayangnya kebebasan menampilkan ekspresi keberagamaan tersebut kerapkali melampaui dari apa yang semestinya. Hal tersebut dapat kita lihat dengan munculnya gerakan keagamaan yang mengusung berbagai macam ajaran, ritual keagamaan yang aneh bahkan cenderung mengancam serta menodai kesucian aqidah, ibadah, ritual, dan pendirian mayoritas ummat yang sudah mapan. Sejak tahun 1989, setidaknya telah ada beberapa aliran keagamaan diberikan label haram oleh MUI (Majelis Ulama Indonesia), diantara aliran yang dianggap menyesatkan itu antara lain: Islam Jama'ah, Ahmadiyah, Ingkar Sunnah, Qur'an Suci, Sholat Dua Bahasa, Lia Eden dan al-Qiyadah al-Islamiyah.

Fenomena ini ditenggarai oleh sebagian pihak sebagai akibat dari kegagalan dakwah. Para da'i dianggap tidak mampu mentransformasikan nilainilai ajaran Islam secara kaffah 
(komprehensif) kepada ummat, dakwah selama ini sering bersifat eksklusif, menghakimi dan memprovokasi. Aktifitas dakwah hanya menampilkan Islam dari aspek langit atau 'ubudiyah (habluminallah) bukan aspek bumi dimana kehidupan sosial (habluminannas) bergulir, sehingga wajar berbagai permasalahan sosial yang dialami ummat tidak tersentuh. Fakta ini menyebabkan ummat mencari solusi lain atas permasalahan sosial yang mereka alami dengan cara "selingkuh" yaitu menganut sekte atau aliran baru dalam sebuah agama yang menawarkan solusi instan, namun cenderung "menyesatkan".

Para da'i, tokoh masyarakat, maupun para pemegang kebijakan ke depan harus mampu merubah paradigma yang selama ini salah dan telah mengkristal di kalangan ummat. Mereka diharapkan tidak berperan sebagai juru dakwah, juru vonis, juru putus, yang hanya menyampaikan pesan bil lisan di atas mimbar saja, tapi lebih dari itu, merek dituntut menjadi -meminjam istilah Clifford Geertz- cultural broker (makelar budaya), bahkan menjadi intermediary forces (kekuatan perantara) bagi permasalahan sosial ummat dalam istilah Hiroko Horikoshi.

Dalam kajian Jurnal Dialog Edisi ini mencoba mengulas tentang Pergeseran Paradigma Menyoroti Gerakan Keagamaan yang kerapkali menghadirkan tematema aktual di tengah-tengah masyarakat. Kajian Jurnal Dialog edisi ini diawali dengan tulisan Prof. Dr. H.M.
Atho Mudzhar tentang Instrumen Internasional dan Peraturan Perundangan Indonesia tentang Kebebasan dan Perlindungan Beragama. Dilanjutkan dengan tulisan Prof. Dr. Abdurrahman Mas'ud yang mengupas tentang Menyikapi Keberadaan Aliran Sempalan.

Sukris Sarmadi, Dosen STAIN Banjarmasin menghadirkan tulisan tentang Transformasi NU dalam Masyarakat Banjar Kini PerspektifPergeseran Gerakan Keagamaan di Kalimantan Selatan. Sedangkan M. Ulinnuha Khusnan, MA melalui tulisannya mencoba memotret Paradigma Keberagamaan Kaum Santri. Nurhasanah dosen UIN Jakarta menghadirkan tulisan tentang Politik Kebijakan Islamisasi Mahathir. Kajian jurnal dialog edisi ini kian lengkap dengan hadirnya tulisan Anwar Mujahidin, MA, tentang Science And Religion (Paradigma Al-Qur'an untuk IlmuIlmu Sosial Menurut Pemikiran Kuntowijoyo).

Di samping memuat artikel ilmiah, Jurnal Dialog edisi ini juga memuat laporan hasil penelitian oleh Ridwan Bustaman, tentang Analisis Wacana Kritis : Tayangan Kekerasan dalam Sinetron Bernuansa Keagamaan. Dan juga hasil penelitian saudara Basuki tentang Pesantren, Tasawufdan Hedonisme Kultural (Studi Kasus Aktualisasi Nilai-nilai Tasawuf dalam Hidup dan Kehidupan di Pondok Pesantren Modern Gontor). Serta hasil penelitian saudari Maryam tentang Interaksi Sosial Pelaku Konversi Agama Etnik Cina.

Kajian ini diakhiri dengan telaah 
buku yang mengulas buku karya Prof. Abdurrahman, 2009 yang berjudul Menebar Rahmat bagi Sekalian Alam. Semoga kajian yang dihadirkan Jurnal Dialog edisi ini memberikan manfaat yang berarti bagi para pembaca, khususnya dalam kajian Pergeseran Paradigma Menyoroti Gerakan Keagamaan. Selamat Membaca!

Redaksi

4 Dialog No. 68, Tahun XXXII, Nopember 2009 
TOPIK

M. Atho Mudzhar

Instrumen Internasional dan Peraturan Perundangan Indonesia tentang Kebebasan dan Perlindungan Beragama - -6

Abdurrahman Mas'ud

Menyikapi Keberadaan Aliran Sempalan --16

SUKRIS SARMADI

Transformasi NU dalam Masyarakat Banjar Kini Perspektif Pergeseran Gerakan Keagamaan di Kalimantan Selatan - 25

\section{Ulinnuha KhuSNAN}

Memotret Paradigma Keberagamaan Kaum Santri —41

\section{NuRHASANAH}

Politik Kebijakan Islamisasi Mahathir —65

\section{Anwar Mujahidin}

Science And Religion (Paradigma Al-Qur'An untuk Ilmu-Ilmu Sosial Menurut Pemikiran Kuntowijoyo) -78

\section{PENELITIAN}

\section{RidWAN Bustamam}

Analisis Wacana Kritis : Tayangan Kekerasan dalam Sinetron Bernuansa Keagamaan $\longrightarrow 97$

\section{BASUKI}

Pesantren, Tasawuf dan Hedonisme Kultural (Studi Kasus Aktualisasi Nilainilai Tasawuf dalam Hidup dan Kehidupan di Pondok Pesantren Modern Gontor) -112

MARYAM

Interaksi Sosial Pelaku Konversi Agama Etnik Cina --135

\section{BOOK REVIEW}

\section{Dewi $\mathbf{N}$}

Menebar Rahmat bagi Sekalian Alam —149 


\title{
Menyikapi Keberadaan Aliran Sempalan
}

\author{
OLEH：ABDURRAHMAN MASUD *)
}

\begin{abstract}
This article discusses the differences in religious interpretation of the scripture and the emergence of various religious beliefs, understanding and sects. Inspite of these differences, most of the religious sects follow the main pillars of their religious teachings and subject to the majority group. Nevertheless, many others tend to pull out from this mainstream group and build another different religious orientation. These so-called splinter groups sometimes oppose againts the teachings developed by the mainstream group. In Islam, as argued by this article, the differences in religious orientations have resulted various reactions and treatments from the rest of the Muslims. The form of the reactions partly relies on the level of the Muslims' educational background. The higher the level of education, the more tolerant the Muslims's attitude toward the religious differences will be.
\end{abstract}

\section{A. Pendahuluan}

Agama menurut para antropolog dan sosiolog merupakan sistem keyakinan yang dianut dan diwujudkan dalam tindakan oleh suatu kelompok atau masyarakat dalam menginterpretasikan dan memberi respon terhadap apa yang dirasakan dan diyakini sebagai sesuatu yang suci dan gaib. Dari pengertian tersebut maka terjadinya perubahan faham dan keyakinan keagamaan sangat memungkinkan. Perubahan tersebut disebabkan karena perbedaan-perbedaan interpretasi dan cara pandang dalam

*) Kepala Pusat Litbang Kehidupan Keagaman Badan Litbang dan Diklat, Depag RI memahami situasi-situasi yang terus berubah atau ilmu pengetahuan yang berkembang meskipun kitab sucinya tidak pernah berubah. (Parsudi Suparlan, 1988).

Perbedaan interpretasi terhadap teks suci atau doktren agama mengakibatkan timbulnya perbedaan keyakinan, faham atau aliran keagamaan, meskipun pada dasarnya ajaran pokoknya menginduk pada kelompok agama yang besar. Jadi secara teoritis dan praktis perbedaan interpretasi terhadap doktrin agama yang menimbulkan aliran agama baru pada tingkat pemahaman pada prinsipnya tidak bisa dihindarkan, terutama karena adanya perbedaan tingkat pengetahuan, pemahaman dan 
pengamalan serta perkembangan budaya masyarakat.

Demikian pula halnya respon masyarakat terhadap adanya perbedaanperbedaan tersebut menyebabkan bentuk dan tingkat reaksi yang beragam. Semakin tinggi pengetahuan dan pemahaman orang terhadap agamanya diharapkan semakin meningkat pula sikap toleransi terhadap pemahaman keagamaan orang lain yang kebetulan berbeda kelompok atau aliran keagamaan. Karena orang yang berpengetahuan dan mempunyai pemahaman keagamaan yang luas cenderung lebih rasional, toleran, dan jauh dari sikap emosional.

Kelompok sempalan (splinter group) adalah kelompok yang ajarannya bertentangan dengan ajaran yang dikembangkan oleh kelompok arus utama (mainstream). Pada umumnya kelompok sempalan bersifat eksklusif, loyalitas terhadap pimpinan sangat tinggi. Selain itu, kelompok ini dalam memahami ajaran agama sangat tekstual-literal, dan menghindari penafsiran ajaran agama secara kontekstual dan fungsional.

\section{B. FAKTOR-FAKTOR YANG Mempengaruhi Pemunculan/ Keberadaan Ajaran/Aliran SEMPalan}

Hasil jajak pendapat yang dilakukan Republika terhadap 1227 responden mengungkapkan, ada empat pemicu dominan munculnya kelompokkelompok sempalan. Pertama, para ulama yang sibuk dengan urusan dunianya. Kedua, penyusupan agenda asing. Ketiga, kemiskinan dan keterbelakangan umat. Keempat, semakin minimnya pendidikan agama. Keempat pemicu tersebut bekerja secara serempak hingga masyarakat memahami agama dengan caranya sendiri. Lalu, dalam jajak pendapat itu, metode dakwah kurang menarik menempati urutan kelima (Republika, 18/ 11/2007).

Berkenaan dengan hal tersebut, Said Aqiel Siradj menyatakan bahwa materi dakwah yang disampaikan monoton dan kurang mendalam diduga kuat menjadi pemicunya. Kondisi ini diperparah ketika dakwah tidak lagi bersifat mengajak, tapi lebih terkesan memprovokasi, sehingga mudah sekali memunculkan kebencian di kalangan umat (Republika, 16/11/2007). Akibatnya, Islam tampil sebagai rumah yang tidak ramah, yang membuat sebagian umat Islam merasa jenuh dan akhirnya mencari ikatan persaudaraan keagamaan yang lebih nyaman. Di sinilah aliran-aliran di atas mengambil peran. Hal senada disampaikan pula oleh Nasaruddin Umar dan M. Quraish Shihab dalam sebuah wawancara (Adil, Edisi 27, II, November-Desember 2007).

\section{Aliran Keagamanan Sempalan Di Berbagai Daerah.}

Beberapa penelitian yang pernah dilakukan oleh Puslitbang Kehidupan Keagamaan antara lain : Ahmadiyah, AlQiyadah Al-Islamiyah, Al-Haq, Lembaga Dakwah Islam Indonesia (LDII), Jamaah Tabligh, dan Saksi-Saksi Yehuwa, Kasus Salafi Versus Non-Salafi, Ajaran Perguruan Mahesa Kurung AlMukarromah Bogor, Jam'iyyatul Islamiyah, Ikatan Jamaah Ahlulbait (IJABI).

Penelitian ini dilatarbelakangi oleh adanya perbedaan interpretasi terhadap teks suci agama yang sering menimbulkan perbedaan keyakinan, faham atau aliran keagamaan. Secara teoritis dan praktis perbedaan aliran baru (aliran sempalan) sering 
menimbulkan respon yang beragam baik datang dari pemerintah, ormas maupun dari masyarakat.

Hasil dari penelitian tersebut adalah $\mathrm{sbb}$ :

\section{a. Ahmadiyah}

Kontroversi di kalangan umat Islam tentang ajaran Ahmadiyah ini belum berubah, yaitu perbedaan tentang pemahaman dan keyakinan Muhammad saw sebagai Khatamun Nabi, adanya wahyu setelah Nabi Muhammad, kewafatan Nabi Isa, Imam Mahdi, Mirza Ghulam Ahmad sebagai nabi yang menerima wahyu dan baiat sebagai anggota. Penanganan yang telah dilakukan Departemen Agama antara lain melakukan pemantauan di beberapa lokasi. Dari hasil pemantauan itu kemudian dikeluarkan SKB Menag, Mendagri dan Jaksa Agung Nomor 3 Tahun 2008, Nomor: Kep-033/A/JA/6/ 2008 dan Nomor 199 Tahun 2008 tentang Peringatan dan Perintah Kepada Penganut, Anggota, dan/atau Anggota Pengurus Jemaat Ahmadiyah Indonesia (JAI) dan Warga Masyarakat.

\section{b. Al-Qiyadah Al-Islamiyah}

Al-Qiyadah Al-Islamiyah adalah sebuah aliran yang dikembangkan oleh Ahmad Mushaddeq (H.Abdussalam). Aliran ini diproklamirkan pada tanggal 23 Juli 2006, bertempat di Gunung Bunder Desa Gunungsari Kecamatan Pamijahan Kabupaten Bogor.

Dalam tempo yang singkat aliran ini sudah tersebar dibeberapa daerah seperti: Batam, Sumatera Barat, Sulawesi Selatan, Lampung, Jakarta, Depok, Jawa Barat dan Yogyakarta. Jumlah pengikut sebanyak 50.000 orang. Aliran ini beralamat di JL Moh Kahfi II No 37 Cipedak, Jagakarsa, Jakarta Selatan, Telp (021) 78893627.
Berdasarkan sumber dari Lembaga Penelitian dan Pengkajian Islam (LPPI), Laporan Komisi Pengkajian dan Pengembangan Majelis Ulama Indonesia, Laporan Kepala Kantor Departemen Agama Kabupaten Bogor dan Laporan Camat Pamijahan, diperoleh informasi tentang beberapa ajaran yang dikembangkan oleh Aliran Al-Qiyadah Al-Islamiyah sebagai berikut:

1. Rasulullah Muhammad SAW telah berakhir masa tugasnya, dan Allah SWT telah mengutus Rasul Baru yaitu Ahmad Mushaddeq yang menamakan dirinya " Al-Masih AlMau'ud"..

2. Syahadatnya dirubah menjadi " Asyhadu an laa ilaaha illa Allah, Wa Asyhadu anna Al-Masih Al-Mau'ud Rasulullah."

3. Kitab sucinya Al-Qur'an, tetapi mereka berkeyakinan bahwa AlQur'an sekarang tinggal tulisann (bacaan) yang tertinggal, sedangkan jiwa (ruhnya) sudah hilang sejak 1300 tahun yang lalu. Rasul AlMasih Al-Mau'ud diutus oleh Allah SWT untuk mengembalikan jiwa (ruh) Al-Qur'an yang hilang tersebut dalam dada setiap muslim, agar hidup jiwanya.

4. Bila seseorang melakukan ibadah tanpa mengikuti rasul setelah Muhammad, yaitu Al-Masih AlMau'ud maka tidak akan diterima ibadahnya.

5. Rasul Al-Masih Al-Mau'ud mewajibkan setriap pengikutnya untuk MITSAQ (bai'at) sebagi bukti telah mengikuti rasul baru Al-Masih Al-Mau'ud.

6. Setelah mendapatkan Ruhul Qudus yang diturunkan oleh Al-Masih AlMau'ud kepada kami, dengan ini 
di[permaklumkan kepada seluruh umat manusia dari segala bangsa, suku, ras dan segenap orang yang membaca kitab ini, bahwa kami adalah orang yang telah bersaksi bahwasanya Al-Masih Al-Mau'ud adalah Rasul Allah, sebagaimana yang telah dinubuwahkan oleh AlQur'an di dalam surat Al-Jum'ah ayat 2 dan 3 sebagai berikut:

"Dialah yang telah membangkitkan dari bangsa yang ummi seorang rasul diantara mereka, yang membacakan ayat-ayat-Nya kepada mereka, mensucikan mereka dan mengajarkan kepada mereka kitab dan hikmah. Dan sesungguhnya mereka sebelumnya benar-benar dalam kesesatan yang nyata. Dan juga kepada bangsa yang lain dari mereka yang belum berhubungan dengan mereka. Dan Dialah Yang Maha Perkasa lagi Maha Bijaksana (QS.62/2-3)."

Selanjutnya masing-masing menyatakan persaksian : Aku bersaksi bahwa Tiada Yang Haq untuk di ibadati kecuali Allah, dan aku bersaksi bahwa Anda Al-Masih Al-Mau'ud adalah utusan Allah".

7. Salat lima waktu tidak wajib karena saat sekarang sudah kembali menjadi periode Makkah karena tidak berlakuknya hukum Islam. Yang wajib adalah qiyamul lail (salat malam) dan salat waktu terbit matahari dan waktu terbenamnya matahari seperti yang dilakukan oleh Rasul Muhammad SAW sewaktu periode Makkah.

8. Bagi mereka yang lalai mengerjakan salat malkam dikenakan kewajiban bayar kafarat (tebus dosa) dan besarnya kafarat tersebut tergantung dari ketetapan atas mereka.

9. Untuk mengembalikan jiwa (ruh) Al-Qur'an yang telah hilang 1300 tahun yang lalu tersebut, kelompok Al-Qiyadah Al-Islamiyah mengartikan ayat-ayat Al-Qur'an secara takwil tidak secara harfiyah. Sebagai contoh Al-Fulk (perahu/kapal) diartikan Al-Qiyadah Al-Islamiyah yang mereupakan komunitas orang yang beriman (jama'ah muslim); yaumul qiyamah diartikan hari berdirinya agama atau hari tegaknya hukum agama.

10. Ada empat hal yang menjadi syarat kesempurnaan diin Islam: a) Rububiyah atau hukum Allah sudah semuanya diajarkan dan dicontohkan penerapannya oleh nabi; b) Mulkiyah atau khilafat sebagai wujud dari kekuasaan Allah yang berfungsi sebagi penegak hukum keadilan Allah sudah cukup kuat; c). Ummat yang akan menjadikan Allah sebagai uluhiyyah (yang disembah) telah aslama telah siap untuk mematuhinya. Ketiga unsur tersebut telah menjadi satu dan berdiri kokoh diatas daar atau bumi Allah.

11. Mereka berjuang ingin mendirikan Negara Islam versi mereka dengan menggunakan 6 (enam) tahap yaitu:

a. Sirrin; gerakan rahasia, berdakwah secara rahasia, megaji secara rahasia, merekrut anggota secara rahasia.

b. Jahrun; berdakwa secara terangterangan, mengaji secara terangterangan, merekrut anggota secara terang-terangan, kalau menurut perhitungan mereka sudah kuat untuk melawan kekuatan kafir.

c. Hijrah; Pindah dari Mekkah ke Madinah (Indonesia ini Mekkah harus hijrah ke Madinah) untuk berdirinya Ibu Kota Negara yang mereka sebut Ummul Qurra'. 
d. Qital; Perang terbuka dengan orang kafir demi keuntungan Negara Islam.

e. Futuh; Menang dari peperangan melawan orang kafir.

f. Khilafah; bentuk pemerintahan Negara Islam versi mereka. Setelah negara Islam terbentuk (khilafah), barulah berlaku hukum Islam versi mereka.

Aliran ini telah dilarang melalui keputusan Jaksa Agung RI Nomor: KEP-116/A/JA/11/2007 tanggal 9 Nopember 2007 tentang Larangan Kegiatan aliran dan ajaran Al-Qiyadah Al-Islamiyah di seluruh Indonesia.

\section{c. Al-Haq}

Pada tahun 2007 muncul sebuah aliran yang menamakan dirinya Al-Haq. Kelompok ini ditengarai telah berkembang di beberapa kota besar di Indonesia, termasuk di kampus-kampus dan kawasan industri. Berdasarkan informasi dari Tim Investigasi Aliran Sesat Forum Ulama Umat Indonesia (TIAS-FUUI) dan melalui internet bahwa doktrin keagamaan kelompok ini bertentangan dengan ajaran Islam, yaitu: (1) Mendoktrinkan bahwa dosa bisa ditebus dengan uang; (2) Menganggap orang lain diluar kelompoknya sebagai kafir; (3) Menyetorkan 25\% dari penghasilannya untuk jama'ah sebagai penebusan dosa; (4) Orang yang keluar dari kelompoknya dinyatakan telah murtad (kafir); (5) Salat dilakukan hanya satu kali dalam sehari semalam; (6) Kewajiban puasa bisa dikonversi dengan uang; (7) Zaman sekarang ini dipandang sebagai zaman belum futuh Makkah, sehingga belum diwajibkan salat, zakat, puasa ataupun ibadah haji.

Apabila dicermati doktrin-doktrin diatas tampaknya ada kecendrungan bahwa kewajiban-kewajiban keagamaan bisa gugur bila dikonversi dengan uang. Jika doktrin ini benar tentu berpengaruh terhadap perilaku pengikutnya.

Terhadap Aliran Kesatuan Al-Haq ini Majelis Ulama Indonesia Kota Pekanbaru telah melakukan pengkajian. Berdasarkan kajian MUI, aliran Kesatuan Al-Haq dinyatakan sebagai aliran yang sesat berdasarkan Keputusan Komisi Fatwa Majelis Ulama Indonesia Pekanbaru Nomor 20 Tahun $1428 \mathrm{H} / 2007 \mathrm{M}$, setelah mendengarkan hasil rapat Komisi Fatwa MUI Kota Pekanbaru pada hari Senin, 24 Syawal 1428 H/ 05 Nopember 2007 M.

Dalam keputusan Komisi Fatwa MUI Pekanbaru aliran ini dianggap sesat berdasarkan hal-hal sebagai berikut:

1. Kelompok ini mengkafirkan orang lain diluar kesatuan mereka, hal ini dianggap bertentangan dengan AlQur'an, akibatnya mereka memiliki doktrin bahwa orang selain mereka adalah musuh sekalipun kaum kerabat. Kaum Muslimin Indonesia adalah kafir bagi kesatuan mereka.

2. Pemahaman tentang Ahlul Kitab. Orang Yahudi dan Nasrani telah meninggalkan Taurat dan Injil maka mereka bukanlah Ahlul Kitab, sebagaimana umat Islam diluar kesatuan mereka telah meninggalkan Al-Qur'an maka mereka bukan lagi Ahlul Kitab. Oleh sebab itu mereka diidentifikasikan sebagai umat yang bukan memiliki kitab (Al-Qur'an).

3. Konsep mereka tentang hijrah (meninggalkan kampung/negeri) hal ini bertentangan dengan hadits Nabi ketika Fathul Makkah. Hijrah menurut mereka adalah masuk dalam kesatuan mereka. 
4. Merahasiakan kegiatan mereka kepada siapapun ( sunnah rahasia).

5. Tujuan kesatuan Al-Haq adalah Iman, Hijrah dan Jihad. Inti semuanya adalah berjihad dan mereka menterjemahkan Tilawah dengan Jihad, pada hal tilawah dalam Islam artinya memperbanyak zikir, bukan berarti Jihad seperti yang mereka pahami.

\section{d. Lembaga Dakwah Islam Indonesia (LDII)}

Secara doktriner, ajaran yang dikembangkan LDII masih dianggap sebagai metamorfosis dari Islam Jamaah, sementara pihak LDII merasa sudah melakukan reformasi dan reposisi. Ajaran-ajaran yang dipermasalahkan antara lain tentang: baiat, manqul, amir, dan sikap eksklusif.

Berdasarkan hasil penelitian tahun 2006 sikap masyarakat di Samarinda, Bolaang Mongondow, Tanjung Pinang dan Palembang, sebagian masih memandang negatif dan curiga, tetapi sebagian yang lain tidak mempermasalahkan lagi karena sudah ada perubahan identitas atau sudah memperbaiki diri.

Sedangkan sikap Pemerintah Daerah dan tokoh Ormas Islam (terutama MUI) sudah tidak mempermasalahkan lagi karena LDII sekarang sudah legal dan sering melakukan komunikasi yang baik dengan jajaran instansi Pemerintah Daerah dan Ormas Islam.

Pada Rakernas LDII tanggal 6-8 Maret 2007 LDII telah mengeluarkan pernyataan sikap pada poin 2 disebutkan: Lembaga Dakwah Islam Indonesia, dalam kebijakan dan programnya menolak secara tegas terhadap opini dan tuduhan negatif yang ditujukan kepada
LDII bahwa LDII masih meneruskan apalagi mengajarkan ajaran Islam Jama'ah. Justru LDII secara terus menerus membina dan meluruskan orang-orang yang masih mempunyai dan melaksanakan ajaran Islam Jama'ah melalui dakwah yang menyejukkan. Dalam kegiatan ibadah, masjid-masjid LDII di seluruh tanah air terbuka untuk umum.

Untuk memantau pernyataan sikap tersebut pada tahun 2008 telah dilakukan penelitian tentang LDII di Surabaya, Semarang, dan Samarinda. Berdasarkan pemantauan tersebut di kalangan pimpinan LDII sudah terjadi "perubahan" meskipun di tingkat awam (grassroot) masih terdapat yang mengamalkan paham Islam Jama'ah. Sekarang ini LDII sedang dalam pembinaan MUI Pusat.

\section{e. Jamaah Tabligh}

Sorotan utama masyarakat terhadap komunitas Jamaah Tabligh ialah praktik dakwah dengan khuruj (meninggalkan rumah) untuk waktu tertentu dan menginap di masjid-masjid (mushalla) secara berkelompok (berjamaah). Implementasi ajaran tersebut dipahami dapat menimbulkan ekses terhadap kehidupan rumah tangganya dan mengganggu keindahan (kebersihan) masjid yang ditinggali. Secara dogmatis atau paham keagamaannya tidak menimbulkan reaksi negatif dari masyarakat atau menimbulkan masalah. Tokoh Ormas Islam dan instansi pemerintah di daerah juga tidak merasa perlu mempersoalkannya, karena selama ini tidak menimbulkan keresahan masyarakat.

\section{f. Saksi-Saksi Yehuwa}

Struktur kepengurusan Saksi-Saksi 
Yehuwa (Jehova Witness) terdiri dari pengurus pusat berada di Broklyn, Pennsylvania, New York, Amerika Serikat. Dibawah pusat terdapat cabang yang berada lebih dari 250 negara, kemudian pengurus wilayah yang terdapat di propinsi, dan dibawah wilayah terdapat pengurus sidang. Saksi-Saksi Yehuwa Indonesia berkantor pusat di Bendungan Hilir, Jakarta Pusat. Saksi-Saksi Yehuwa di Indonesia didirikan oleh M.T.P Hutasoit, dibantu oleh Sony Soedarsono, Budi Sentosa, Mario Koetin, R. Simatupang dan V.Ipikkusuma.

Ajaran yang dikembangkan oleh Saksi-Saksi Yehuwa sangat bertentangan dengan ajaran yang dikembangkan oleh gereja-gereja arus utama. Ajarannya menolak konsep Trinitas, tidak menggunakan simbol Salib, tidak merayakan Natal, tidak mempercayai adanya neraka, tidak mengakui kitab suci lain, selain kitab suci milik mereka yaitu Alkitab terjemahan Dunia Baru (New World Translation). Selain itu yang sering dipermasalahkan masyarakat yaitu tidak mau menghormati bendera, menyiarkan agama dari rumah ke rumah, tidak boleh jadi tentara dan polisi.

Munculnya kasus ini disebabkan keluarnya Saksi-Saksi Yehuwa ini pernah dilarang oleh Kejaksaan Agung tahun 1976 melalui Keputusan Jaksa Agung Republik Indonesia Nomor Kep 129/JA/12/1976 Tanggal 7 Desember 1976 Perihal Pelarangan Terhadap Ajaran/ Perkumpulan Siswa-Siswa Alkitab/ Saksi-Saksi Yehova. Pada tahun 2001 keputusan tersebut dicabut melalui Keputusan Jaksa Agung Republik IndonesiaNomor: Kep- 255/A/JA/06/ 2001, Tentang Pencabutan Keputusan Jaksa Agung Republik Indonesia Nomor
Kep 129/JA/12/1976 Tanggal 7 Desember 1976 Perihal Pelarangan Terhadap Ajaran/Perkumpulan Siswa-Siswa Alkitab/Saksi-Saksi Yehova. Dengan keluarnya Keputusan Jaksa Agung tersebut maka Gereja Saksi-saksi Yehuwa diperbolehkan kembali untuk mengadakan aktivitasnya.

Keluarnya SK tersebut mendapat protes dari 22 denominasi yang ada di Provinsi Nusa Tenggara Timur, mereka meminta agar pendaftaran organiasi Saksi-Saksi Yehuwa ditolak oleh Bidang Bimas Kristen Kanwil Deparatemen Agama Provinsi Nusa Tenggara Timur.

\section{g. Kasus Salafi Versus Non-Salafi di Lombok Barat Provinsi Nusa Tenggara Barat.}

Munculnya konflik antara kelompok Salafi dan Non Salafi adalah karena munculnya metode dakwah yang bersifat eksklusif dan menyalahkan orang lain. Juga karena kurangnya sikap menghargai perbedaan pendapat. Konflik ini terus berlanjut karena pihak pemerintah daerah setempat tidak berani membuat keputusan yang berkaitan dengan pelanggaran Hak Azasi Manusia (HAM). Disamping itu solusi yang diambil oleh pejabat-pejabat setempat terlalu memihak kepada kelompok tertentu, sehingga bagi kelompok yang lain kebijakan yang diambil oleh pejabat setempat dirasa tidak memuaskan semua pihak. Pada hal, menurut beberapa tokoh masyarakat dan agama, dari segi ajaran aliran Salafi ini tidak menunjukkan ke arah sesat. Jadi dapat dikatakan bahwa munculnya konflik itu adalah karena komunikasi yang kurang lancar antar kelompok dalan menghadapi masalah khilafiah. 


\section{h. Jam'iyyatul Islamiyah}

Jam'iyyatul Islamiyah adalah organisasi sosial keagamaan yang terus mengembangkan dirinya menjadi organisasi yang solid. Kegiatan utamanya adalah mengembangkan syiar Islam dengan melakukan pengajian dan mendirikan masjid. Saat ini Jam'iyyaatul Islamiyah memiliki pengikut dari berbagai elemen kelompok masyarakat. Dalam perkembangannya, Jam'iyyatul Islamiah mendapat banyak tantangan karena diduga mengajarkan aliran sesat.

Pada perkembangan terakhir telah terjadi dialog antara Pengurus MUI Pusat dengan Pengurus Pusat Jam'iyyatul Islamiyah, dan setelah diadakan dialog dan pembinaan oleh Pengurus MUI Pusat, kelompok ini sudah dianggap rujuk ilal haq.

\section{i. Ikatan Jamaah Ahlulbait (IJABI) di Bandung}

Ikatan Jama'ah Ahlulbait (IJABI) pada dasarnya merupakan gerakan keagamaan yang berusaha menerjemahkan realitas kehidupan keagamaan di Indonesia, baik simbol maupun substansinya. Ahlulbait adalah keluarga Imam Ali dan para pengikutnya.

IJABI dideklarasikan di Gedung Merdeka Bandung pada Mu'tamar ke 1, tahun $2000 \mathrm{M} / 1421 \mathrm{H}$. Tokoh pendirinya adalah Dr. H. Jalaluddin Rahmat M.Sc dan Dr. Ir. Damitri Mahayana, M. Ing. Pendirian IJABI yang didasarkan salah satunya adalah ingin mengembangkan ajaran Islam dari sudut pemahaman ahlulbait. Ini dapat diterjemahkan sebagai respon terhadap ajaran Islam yang sudah mapan selama ini karena dipandang kurang lengkap sumber rujukannya tanpa melibatkan pemahaman ahlulbait itu. Dapat juga diterjemahkan sebagai ketidakpuasan atas realitas keagamaan yang sudah berjalan sejak berabad-abad sejak munculnya Khalifah Mu'awiyah, karena sejak saat itu ahlulbait tersingkir dan tertutup semua aksesnya.

Pendirian Ikatan Jama'ah Ahlulbait Indonesia dilatarbelakangi oleh kecintaan kepada Ahlulbait oleh kaum muslimin Indonesia apapun mazhab dan pemahaman keagamaannya. Menurut mereka bahwa kecintaan kepada Allah tidak dapat dilakukan tanpa melalui kecintaan kaum muslimin kepada Rasulullah saw. Kecintaan kepada Rasulullah tidak dapat dipenuhi tanpa ada kecintaan kepada Ahlulbait atau keluarga Bani Hasyim.

Masyarakat menganggap keberadaan IJABI sebagai pelopor bangkitnya ajaran Syi'ah di Indonesia, meskipun dalam realitanya jarang berbicara soal Syi'ah. Walaupun tanggapan dari berbagai kalangan bahwa berdirinya IJABI tidak ada masalah, namun mereka menjadi bertanya-tanya mengapa yang dikembangkan dan diajarkan tentang Islam yang sesuai dengan pemahaman jalur ahlulbait.

\section{Cara Menyikapi dan Menyelesaikan Keberadaan Ajaran/Aliran Sempalan}

1. Dilakukan dialog antara aparat Depag dengan kelompok yang dianggap sempalan.

2. Mengembangkan ajaran agama yang toleran dan moderat.

3. Meningkatkan metodologi dakwah sesuai dengan berbagai segmen masyarakat.

4. Dibentuk lembaga semi pemerintah yang menangani krisis, semacam "Centre for Religious Crisis" atau "Centre for Caring Religious Problem". 
5. Melakukan mediasi terhadap kelompok-kelompok yang sedang mengalami konflik.

6. Mendewasakan keberagamaan masyarakat untuk bisa menerima perbedaan paham keagamaan.

\section{E. Rekomendasi}

Beberapa Rekomendasi yang dikeluarkan dari hasil penelitian tersebut sbb:

1. Pemerintah Daerah hendaknya merumuskan kebijakan terkait dengan keagamaan misalnya aktif membimbing kehidupan masyarakat menuju toleransi antar aliran. Sementara MUI dan lembaga keagamaan lainnya hendaknya mengambil peran sebagai penengah/ mediator bagi berbagai kelompok yang selama ini berpotensi konflik dan tidak mudah menyalahkan satu kelompok agama sebagai kelompok sesat. Kelompok keagamaan yang diduga menyebarkan ajaran sesat, sebaiknya menuliskan ajarannya melalui buku atau media lainnya sehingga masyarakat dapat mengkaji ajarannya.

2. Hendaknya pemerintah mendorong MUI serta pengurus ormas-ormas Islam bersama dengan kelompokkelompok yang dianggap sempalan untuk melakukan dialog dalam upaya mendekatkan hubungan yang lebih harmonis.

3. Perlu adanya ketegasan sikap dari Departemen Agama c.q. Dirjen Bimas Kristen tentang keberadaan SaksiSaksi Yehuwa di Indonesia. Sebab di beberapa daerah masih terdapat penolakan dari Pembimas Kristen Kanwil Departemen Agama Provinsi untuk menerima pendaftaran SaksiSaksi Yehuwa sebagai organisasi keagamaan Kristen.

4. Disarankan kepada juru dakwah dalam menyampaikan dakwahnya agar bersifat mengajak bukan memprovokasi.

5. Disarankan kepada lembagalembaga dakwah atau organisasiorganisasi keagamaan untuk mengembangkan wawasan keagamaan masyarakat yang bersifat terbuka, inklusif, toleran, dan moderat.[] 